\title{
Milk production per cow and per hectare of spring-calving dairy cows grazing swards differing in Lolium perenne L. ploidy and Trifolium repens L. composition
}

\author{
B. McClearn, ${ }^{1,2}$ T. J. Gilliland, ${ }^{2,3}$ L. Delaby, ${ }^{4}$ C. Guy, ${ }^{1,2}$ M. Dineen, ${ }^{1}$ F. Coughlan, ${ }^{1}$ and B. McCarthy ${ }^{1 *}$ \\ ${ }^{1}$ Teagasc, Animal \& Grassland Research and Innovation Centre, Moorepark, Fermoy P61C996, Co. Cork, Ireland \\ ${ }^{2}$ Institute of Global Food Security, Queen's University Belfast, Belfast BT95DL, United Kingdom \\ ${ }^{3}$ Agri-food Biosciences Institute, Hillsborough, BT26 6DR, United Kingdom \\ ${ }^{4}$ INRA, AgroCampus Ouest, UMR Physiologie, Environnement, Génétique pour l'Animal et les Systèmes d'Elevage, St. Gilles 35590, France
}

\section{ABSTRACT}

Grazed grass is the cheapest feed available for dairy cows in temperate regions; thus, to maximize profits, dairy farmers must optimize the use of this high-quality feed. Previous research has defined the benefits of including white clover (Trifolium repens L.) in grass swards for milk production, usually at reduced nitrogen usage and stocking rate. The aim of this study was to quantify the responses in milk production of dairy cows grazing tetraploid or diploid perennial ryegrass (Lolium perenne L.; PRG) sown with and without white clover but without reducing stocking rate or nitrogen usage. We compared 4 grazing treatments in this study: tetraploid PRG-only swards, diploid PRG-only swards, tetraploid with white clover swards, and diploid with white clover swards. Thirty cows were assigned to each treatment, and swards were rotationally grazed at a farm-level stocking rate of 2.75 cows/ha and a nitrogen fertilizer rate of $250 \mathrm{~kg} / \mathrm{ha}$ annually. Sward white clover content was 23.6 and $22.6 \%$ for tetraploid with white clover swards and diploid with white clover swards, respectively. Milk production did not differ between the 2 ploidies during this 4-yr study, but cows grazing the PRG-white clover treatments had significantly greater milk yields $(+596 \mathrm{~kg} / \mathrm{cow}$ per year $)$ and milk solid yields $(+48 \mathrm{~kg} /$ cow per year) compared with cows grazing the PRG-only treatments. The PRG-white clover swards also produced 1,205 kg of DM/ha per year more herbage, which was available for conserving and buffer feeding in spring when these swards were less productive than PRG-only swards. Although white clover is

Received December 19, 2018.

Accepted May 7, 2019.

*Corresponding author: brian.mccarthy@teagasc.ie generally combined with reduced nitrogen fertilizer use, this study provides evidence that including white clover in either tetraploid or diploid PRG swards, combined with high levels of nitrogen fertilizer, can effectively increase milk production per cow and per hectare.

Key words: perennial ryegrass ploidy, white clover, grazing systems, milk production

\section{INTRODUCTION}

Fast-growing worldwide demand for dairy products, particularly in developing countries, and increasing concern over the environmental impact of dairy farming creates a need for efficient as well as sustainable farming practices (van Vuuren and Chilibroste, 2013). The suitability of Ireland's climate for forage production has given it a competitive advantage for producing high-quality milk from low-cost grazed herbage. Grazed perennial ryegrass (Lolium perenne L.; PRG) is the cheapest feed available for dairy cows; therefore, to maximize profits, dairy farmers should use this high-quality feed where possible (Dillon et al., 2005; Finneran et al., 2012). In suitable temperate regions, grass can constitute up to $80 \%$ of dairy cow diets, thus the production and utilization of grazed grass can significantly increase farm profitability (Macdonald et al., 2010). Good grazing management for spring-calving milk production systems requires compact calving in spring to match animal demand to grass supply, along with the optimum stocking rate suited to the land (O'Donovan et al., 2011).

Perennial ryegrass is one of the most important grass species grown in temperate pastoral regions of the world (McGilloway, 2005). Diploid and tetraploid PRG cultivars differ in nutritional value and growth habit, and tetraploid cultivars have been shown to provide a small positive impact on milk production per cow compared with diploid cultivars (Castle and Watson, 1971; Lantinga and Groot, 1996; Wims et al., 2013). The 
morphological plant differences between PRG ploidies include tetraploid cultivars having a higher proportion of cellular content, which provides a higher concentration of water-soluble carbohydrates, protein, and lipids and improves digestibility (Smith et al., 2001). Tetraploid cultivars have fewer tillers than diploid cultivars but have a much larger leaf size. Previous research has shown an animal preference for grazing tetraploid cultivars compared with diploid cultivars (Balocchi and López, 2009), and tetraploid cultivars support higher sward white clover (Trifolium repens L.) content compared with diploid cultivars under sheep and cattle grazing (Gooding et al., 1996; Stilmant et al., 2005).

White clover inclusion in PRG swards can play a role in sustainable agriculture because its ability to biologically fix $\mathrm{N}$ can lead to a reduction in inorganic $\mathrm{N}$ fertilizer application rates while maintaining or increasing herbage DM production and herbage nutritive value (Lüscher et al., 2014; Delaby et al., 2016). Recent studies have confirmed that including white clover in PRG swards can have a positive effect on herbage production as well as animal performance (Enriquez-Hidalgo et al., 2014; Egan et al., 2018), with a milk production increase of 15 to $20 \%$ observed when cows grazed PRGwhite clover swards versus PRG-only swards (Phillips and James, 1998). The increase in milk production has been associated with higher herbage nutritive value from PRG-white clover swards, especially in midseason, compared with PRG (Søegaard, 1993) and an increase in voluntary herbage DM intake (Ribeiro Filho et al., 2005), with numerous studies having shown selective grazing of white clover over PRG (Gooding et al., 1996; Rutter et al., 2004). A recent meta-analysis reported that cows grazing PRG-white clover swards produced an additional $1.4 \mathrm{~kg}$ milk/cow per day compared with cows grazing PRG-only swards, while milk production per hectare was similar due to the lower stocking rate and reduced $\mathrm{N}$ fertilizer application rates associated with PRG-white clover swards (Dineen et al., 2018). Dineen et al. (2018) hypothesized that an increased stocking rate with PRG-white clover swards and $\mathrm{N}$ fertilizer could increase productivity from grass-based production systems. However, the environmental impacts and the negative correlation between $\mathrm{N}$ use and white clover persistence would need to be carefully examined (Ledgard et al., 2009).

The objective of this study was to determine the effect of PRG ploidy (tetraploid and diploid) sown with and without white clover, at the same stocking rate and $\mathrm{N}$ fertilization level, on milk production per cow and per hectare of grazing dairy cows in a spring-calving grass-based production system.

\section{MATERIALS AND METHODS}

\section{Experimental Design and Treatments}

The experiment was a randomized block design with a $2 \times 2$ factorial arrangement of treatments. The experiment was established in Teagasc Clonakilty Agricultural College, Co. Cork $\left(51^{\circ} 63^{\prime} \mathrm{N},-08^{\circ} 85^{\prime} \mathrm{E}\right.$; 25-70 m above sea level) and ran for 4 yr from 2014 to 2017. A dairy grazing platform of 43.6 ha was used, with $75 \%$ of the experimental area reseeded in 2012 and $25 \%$ reseeded in 2013 by full cultivation (plowing and tilling). Four separate grazing treatments were sown, a tetraploid PRG-only sward (TGO), a diploid PRG-only sward (DGO), a tetraploid PRG sward with white clover (TWC), and a diploid PRG sward with white clover (DWC). The 4 tetraploid cultivars ('Astonenergy', 'Dunluce', 'Kintyre', and 'Twymax', sown at $37.5 \mathrm{~kg} / \mathrm{ha}$ ) and 4 diploid cultivars ('Aberchoice', 'Glenveagh', 'Tyrella', and 'Drumbo', sown at $30 \mathrm{~kg} /$ ha) were sown as monocultures, with each cultivar sown 10 times across the grazing platform. In the white clover paddocks a 50:50 mix of the medium-leaved white clover cultivars 'Chieftain' and 'Crusader' were sown at $5 \mathrm{~kg} / \mathrm{ha}$. Overall, 4 farmlets were created, with 20 paddocks per grazing treatment for the $4 \mathrm{yr}$. Paddocks for each treatment were balanced for location block, soil type, and soil fertility throughout the farm. Each farmlet was 10.9 ha and stocked at 2.75 cows/ha. Thirty spring-calving dairy cows were assigned to each grazing treatment every year based on breed, parity, calving date, BW, BCS, and Economic Breeding Index (EBI). Three cow breeds were used for this experiment; Holstein Friesian, Jersey $\times$ Holstein Friesian, and $($ Jersey $\times$ Holstein Friesian $) \times$ Norwegian Red

\section{Grazing Management}

All treatments were grazed in a spring-calving rotational system. Cows were grazed day and night as they calved from February onward as soon as weather conditions allowed. Typically, grazing began in early February and finished in mid-November each year. Cows were supplemented with $4 \mathrm{~kg}$ of concentrate post calving, and this supplement was gradually reduced as grass growth on the treatments met demand. Grazing management was achieved by weekly monitoring of average farm cover for each treatment and using the online application PastureBase to aid in decision making (Hanrahan et al., 2017). Target pregrazing herbage mass (PrGHM) was calculated separately for each grazing treatment using the following formula: 
Target $\operatorname{PrGHM}=($ stocking rate $\times$ ideal rotation

$$
\begin{gathered}
\text { length } \times \text { daily herbage allowance per cow) } \\
+ \text { residual herbage mass. }
\end{gathered}
$$

If a herbage deficit occurred across all treatments, then concentrate supplementation was increased for all groups. However, if a herbage deficit occurred in fewer than all 4 treatments, then silage produced from each treatment was used to supplement the deficit to each individual treatment group. During periods of inclement weather conditions (excessive rainfall), when grazing conditions were poor, on-off grazing was practiced (Kennedy et al., 2009).

Residency time within paddocks was determined by targeting a postgrazing sward height (PoGSH) of 3.5 to $4 \mathrm{~cm}$ for the first and final grazing rotation and a target of 4 to $4.5 \mathrm{~cm}$ throughout the main grazing season. Cows within treatments were moved to their following paddocks when the target PoGSH was reached. No topping of paddocks took place during the $4 \mathrm{yr}$, and all excess forage was removed and conserved as silage. Inorganic $\mathrm{N}$ was applied equally across all 4 treatments in the form of urea or calcium ammonium nitrate at a rate of $250 \mathrm{~kg}$ of $\mathrm{N} /$ ha per year. Inorganic $\mathrm{P}$ and $\mathrm{K}$ were applied at similar rates across all 4 treatments based on yearly soil test results.

\section{Herbage Measurements}

Grazing data were collected at each grazing for each treatment. Pregrazing herbage mass was determined before grazing by harvesting 2 strips (approximately 10 $\mathrm{m} \times 1.2 \mathrm{~m}$ ) to a height of $4.0 \mathrm{~cm}$ using an Etesia mower (Etesia UK Ltd., Warwick, UK). The harvested forage was weighed and a $100-\mathrm{g}$ subsample was dried at $90^{\circ} \mathrm{C}$ for $15 \mathrm{~h}$ to determine DM. A combined sample from the 2 harvested strips was frozen, freeze-dried, and milled. These samples were analyzed at 4 time points (February/March, mid-May/mid-June, mid-June/mid-July, September) across the year for DM content, ash content, ADF, NDF (Van Soest, 1963), CP (Association of Official Analytical Chemists, 1990), and organic matter digestibility (OMD; Morgan et al., 1989). Ten sward heights were taken before and after each strip of forage was harvested using a rising platemeter (Jenquip, Feilding, New Zealand), and used to calculate sward density as follows:

$$
\begin{aligned}
& \text { Sward density ( } \mathrm{kg} \text { of } \mathrm{DM} / \mathrm{cm})=\text { PrGHM/ } \\
& \text { (precutting height - postcutting height). }
\end{aligned}
$$

Pregrazing sward height (PrGSH) and PoGSH were also calculated across whole paddocks before and after grazing using a platemeter taking compressed sward heights at 30 locations pregrazing and 50 compressed sward heights following grazing.

Pregrazing herbage mass above $4 \mathrm{~cm}$ was calculated using sward density according to the following equation:

Pregrazing herbage mass above $4 \mathrm{~cm}$

$(\mathrm{kg}$ of DM $/ \mathrm{ha})=(\mathrm{PrGSH}-4 \mathrm{~cm}) \times$ sward density

\section{Herbage Production and Use}

Herbage production was categorized as grazing herbage production or silage production. All herbage production was recorded and calculated using the online application PastureBase. Herbage removed and grazing efficiency were calculated as follows:

$$
\begin{gathered}
\text { Herbage removed }(\mathrm{kg} \text { of DM } / \mathrm{ha})= \\
(\text { PrGSH }- \text { PoGSH }) \times \text { sward density; } \\
\text { Grazing efficiency }=\text { herbage removed/PrGHM. }
\end{gathered}
$$

Daily herbage allowance and daily herbage removed were then calculated based on the residency time within each paddock. Grazing data were analyzed for 3 periods of the grazing season: spring (turnout to March 31), summer (April 1 to August 31), and autumn (September 1 to housing).

\section{Clover Contribution}

White clover content was estimated in each paddock before every grazing event. A Gardena hand shears (Accu 60; Gardena International GmbH, Ulm, Germany) was used to take 15 random herbage samples cut to $4 \mathrm{~cm}$ throughout the paddock. The herbage sample was then mixed, and two 70-g cut-samples were weighed and separated by hand into white clover, PRG, and other plant fractions and dried at $60^{\circ} \mathrm{C}$ for $48 \mathrm{~h}$ to determine proportions on a DM basis.

\section{Animal Measurements}

Cows were milked twice daily at approximately 0700 and $1530 \mathrm{~h}$. Weekly milk production was derived from individual milk yields $(\mathrm{kg})$ recorded at each milking (Dairymaster, Causeway, Co. Kerry, Ireland). Milk fat, protein, and lactose content was determined weekly from 
a consecutive afternoon and morning milk sample for each cow and tested using infrared spectrophotometry (Milkoscan 203 [DK-3400], Foss Electric, Hillerød, Denmark). Milk solids ( $\mathrm{kg}$ of fat + protein; MS) yield per cow was also calculated. Cows were weighed fortnightly during lactation upon exit from the milking parlor using an electronic scale (Tru-Test Ltd., Auckland, New Zealand). Body condition score was assessed fortnightly by the same individual throughout the study on a scale of 1 to 5 in increments of 0.25 (where 1 = emaciated, 5 = extremely fat) as outlined by Edmonson et al. (1989).

Milk, fat, protein, lactose, and MS yield per hectare were calculated by calculating the total milk and MS produced from each paddock in each treatment and dividing by the area of the paddock to give the yield per hectare as described by McCarthy et al. (2013). Similarly, grazing days per hectare was calculated for each paddock by calculating the total number of cow grazing days in each paddock in each treatment and dividing by the area of the paddock.

\section{Statistical Analysis}

Herbage Production and Dietary Details. All data were analyzed using SAS 9.4 software (SAS Institute Inc., Cary, NC). Pregrazing herbage mass, PrGSH, PoGSH, density, herbage DM, weekly growth rate, and sward white clover content were analyzed using PROC MIXED, with year, ploidy, white clover treatment, rotation, and the associated interactions included in the model. Individual paddock was the experimental unit, with paddock included as a random factor and rotation as a repeated measure. A compound symmetry covariance structure among records within paddock was used. Sward nutritive value was analyzed using PROC GLM, with year, time point, ploidy, white clover treatment, and PRG cultivar included in the model. Concentrate and silage supplementation was analyzed by PROC MIXED with cow as the experimental unit, taking into account the effects of year, ploidy, white clover treatment, parity, breed, and their subsequent interactions. Tukey's test was used to determine differences between treatment means. Significance was declared at $P<0.05$ and a tendency at $P>0.05$ and $P<0.10$.

Milk Production per Cow and per Hectare. Animal variables such as daily milk yield; fat, protein, and lactose content; daily MS; cumulative milk and MS yield; BW; and BCS were analyzed using PROC MIXED, taking into account the effects of year, ploidy, white clover treatment, parity, breed, and their subsequent interactions. Individual cow was the experimental unit. Lactation length and the EBI subindex for milk, fat, protein, and MS centered within parity and breed were included as covariates in the model for each re- spective analysis. The lactation was broken down into 3 distinct periods: period 1 (corresponding to the first 14 wk of lactation), period 2 (corresponding to wk 15-28 of lactation), and period 3 (corresponding to wk 29-42 of lactation). All 3 periods were analyzed as described previously. For milk, fat, protein, lactose, MS yield, and grazing days per hectare, paddock was the experimental unit, and variables were analyzed separately using PROC MIXED, with the effect of year, location block, ploidy, white clover treatment, number of silage cuts, and their interactions included in the model. Tukey's test was used to determine differences between treatment means. Significance was declared at $P<0.05$ and a tendency at $P>0.05$ and $P<0.10$.

Reproductive Performance. The responses to different ploidy and white clover treatments on calving date, calving to first service interval, calving to conception interval, and number of services per cow were analyzed using PROC MIXED, taking into account the effects of year, ploidy and white clover treatments, parity, breed, and their subsequent interactions. Individual cow was the experimental unit. A logistic regression model (PROC LOGISTIC) that included the effects of ploidy, white clover treatment, breed, and parity, with the fertility subindex of the EBI centered within breed and parity included as a covariate, was used to determine 24-d submission rate, pregnancy rate to first service, pregnancy rate to second service, 6 -wk pregnancy rate, embryo mortality, and overall pregnancy rate.

\section{Meteorological Data}

Mean monthly rainfall and air and soil temperature data for each year of the study and the 10-yr averages are presented in Table 1. Weather conditions varied among all $4 \mathrm{yr}$ of the study. Mean air and soil temperatures for the 4 yr remained consistent with 10-yr averages. Mean air temperature for the $4 \mathrm{yr}$ was slightly higher than the previous 10 -yr average $\left(+0.3^{\circ} \mathrm{C}\right)$; this difference was also reflected in the mean soil temperature being slightly higher $\left(+0.6^{\circ} \mathrm{C}\right)$. Rainfall was extremely variable; in 2015, rainfall was $422 \mathrm{~mm}$ above the 10-yr average with May (+61 mm), September (+85 mm), November $(+39$ $\mathrm{mm})$, and December in particular $(+261 \mathrm{~mm})$ being the months with higher-than-average rainfall. Extended periods of adverse weather (e.g., drought or snow) did not occur during the trial period and therefore did not negatively affect this grazing study.

\section{RESULTS}

\section{Sward Measurements}

Herbage Production and Grazing Characteristics. The 4-yr average grazing season length was 286 
Table 1. Meteorological data for the experimental period 2014-2017 compared with the previous 10-yr average (2004-2014)

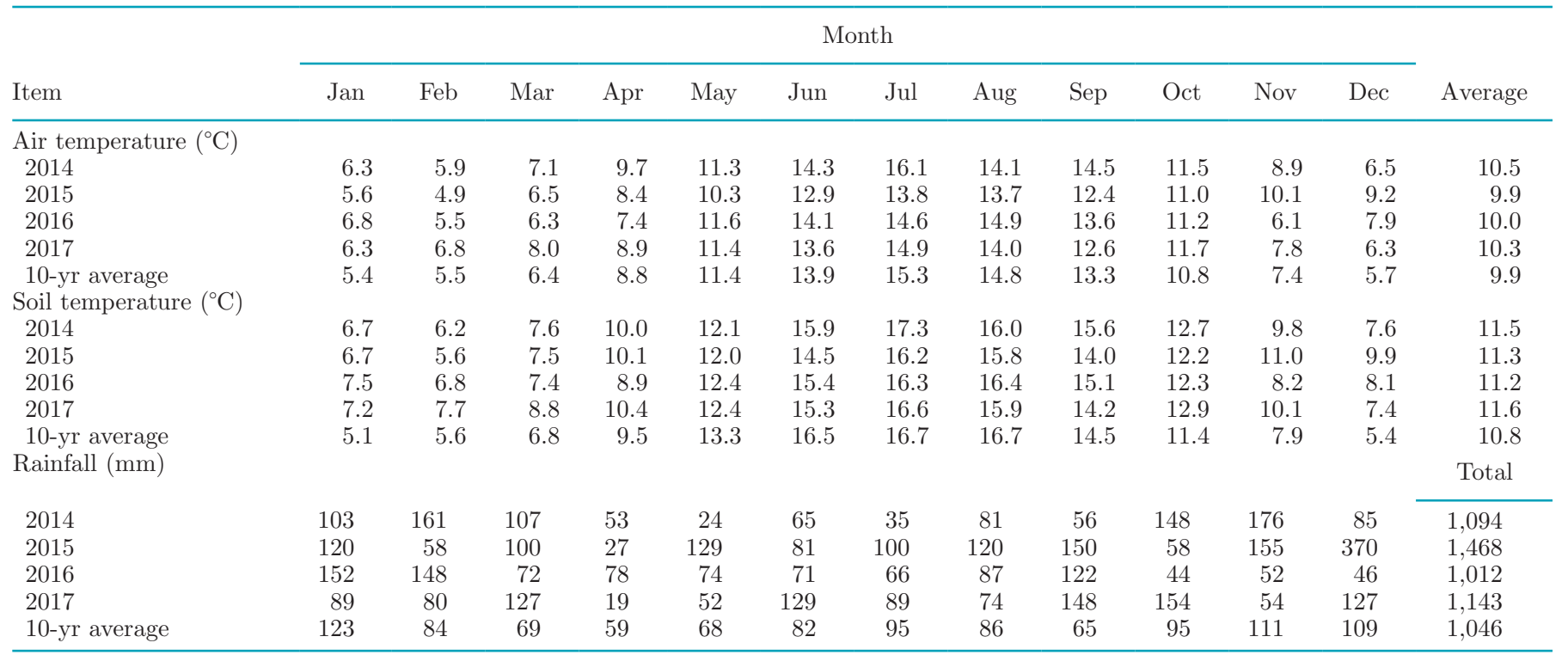

and 281 d, respectively, for PRG-only (TGO and DGO) and PRG-white clover (TWC and DWC) treatments. Full days at grass for PRG-only and PRG-white clover groups were 247 and $240 \mathrm{~d}$, respectively. Weekly herbage growth rate did not vary between the 2 PRG ploidies. Consequently, herbage production did not differ between tetraploid (16,211 $\mathrm{kg}$ of $\mathrm{DM} / \mathrm{ha})$ and diploid (16,136 kg of DM/ha) swards seasonally or cumulatively. On average, PRG-white clover swards had a higher growth rate over the grazing season $(+7.3 \mathrm{~kg}$ of $\mathrm{DM} /$ ha per day; 60.9 vs. $53.7 \mathrm{~kg}$ of $\mathrm{DM} /$ ha per day for PRG-white clover and PRG-only swards, respectively; Figure 1). Cumulative herbage DM production was significantly increased by white clover inclusion, with PRG-white clover swards producing on average 1,205 $\mathrm{kg}$ of $\mathrm{DM} /$ ha per year more than PRG-only swards $(15,643$ and 15,494 kg of DM/ha per year for TGO and DGO, respectively, vs. 16,779 and $16,773 \mathrm{~kg}$ of DM/ha for TWC and DWC per year, respectively). This extra herbage was produced in summer $(+892 \mathrm{~kg}$ of $\mathrm{DM} /$ ha; 11,576 vs. $12,468 \mathrm{~kg}$ of DM/ha for PRG-only and PRG-white clover, respectively) and autumn $(+237$ $\mathrm{kg}$ of DM/ha; 3,055 vs. 3,291 kg of DM/ha for PRGonly and PRG-white clover, respectively), with all 4 grazing treatments having similar herbage production during spring. Perennial ryegrass-white clover swards produced more grazing DM (11,950 vs. $11,320 \mathrm{~kg}$ of $\mathrm{DM} /$ ha; $P=0.032$ ) and tended to produce more silage DM $(4,826$ vs. $4,250 \mathrm{~kg}$ of $\mathrm{DM} / \mathrm{ha} ; P=0.075)$ than PRG-only swards.

Diploid and tetraploid white clover swards had similar sward white clover content on average during the 4 yr (23.6 and 22.6\%, respectively; Table 2). However, large variations in sward white clover content occurred between paddocks and seasons. White clover content was lowest in February for all $4 \mathrm{yr}$ of the study and highest from August to October (Figure 2).

The DM content of the swards varied significantly between ploidy, with diploid swards having a consistently higher DM content compared with tetraploid swards (18.8 vs. $17.9 \%$ ). Diploid swards had a higher PrGHM $(1,673 \mathrm{~kg}$ of $\mathrm{DM} / \mathrm{ha})$ than tetraploid swards (1,584 kg of DM/ha; Table 2); however, their PrGSH did not differ (average $8.8 \mathrm{~cm}$ ). Tetraploid swards had a lower PoGSH compared with diploid swards (4.10 vs. $4.32 \mathrm{~cm}$; Table 2). Diploid swards tended to have a higher density compared with tetraploid swards (332 vs. $326 \mathrm{~kg}$ of $\mathrm{DM} /$ ha per centimeter; $P=0.074$ ).

Dry matter content of PRG-white clover swards was significantly lower than PRG-only swards (17.2 vs. $19.4 \%$ ). Perennial ryegrass-white clover swards had a lower average PrGHM (1,579 kg of DM/ha) compared with PRG-only swards $(1,678 \mathrm{~kg}$ of $\mathrm{DM} / \mathrm{ha})$ throughout the year. White clover inclusion was associated with a 0.24-cm lower PrGSH compared with PRG-only swards ( 8.56 vs. $8.8 \mathrm{~cm}$ ), and including white clover in the swards lowered PoGSH compared with PRG-only swards (3.85 vs. $4.21 \mathrm{~cm}$ ). Perennial ryegrass-white clover swards had a slightly lower density compared with PRG-only swards (326 vs. $332 \mathrm{~kg}$ of DM/ha per centimeter).

Dietary Details and Nutritive Value. No interaction was observed between ploidy and white clover inclusion. Diploid swards provided a higher herbage allowance than the tetraploids (15.8 vs. $15.1 \mathrm{~kg}$ of $\mathrm{DM} /$ cow per day, respectively) in the summer (16.2 
vs. $15.3 \mathrm{~kg}$ of $\mathrm{DM} /$ cow per day, respectively) but not in spring and autumn (Table 2). Tetraploid and diploid swards had similar average herbage removal levels across each season and across the full year. Tetraploid swards achieved a higher grazing efficiency compared with diploid swards (1.04 vs. 1.00) due to their lower PoGSH. No differences were observed in CP between the ploidies, but diploid swards had higher NDF $(+21.2$ $\mathrm{g} / \mathrm{kg}$ of DM), ADF, and ash content, whereas tetraploid swards had higher OMD content (792 vs. $780 \mathrm{~g} / \mathrm{kg}$ of $\mathrm{DM})$, representing an average OMD difference of 11.3 $\mathrm{g} / \mathrm{kg}$ of DM (Table 3$)$.

A tendency $(P=0.066)$ existed for PRG-white clover swards to have a lower herbage allowance across the grazing season (15.2 kg of DM/cow per day) compared with PRG-only swards (15.7 kg of DM/cow per day), with significantly lower herbage allowance for PRGwhite clover treatments in spring (13.5 vs. $16.4 \mathrm{~kg}$ of $\mathrm{DM} /$ cow per day). The average herbage removed over the grazing season was $15.7 \mathrm{~kg}$ of $\mathrm{DM} / \mathrm{cow}$ per day for PRG-white clover and $14.9 \mathrm{~kg}$ of DM/cow per day for PRG-only treatments. Herbage removed differences were most significant in summer, with cows removing $15.7 \mathrm{~kg}$ of $\mathrm{DM} /$ cow per day from PRG-white clover swards compared with PRG-only (14.4 kg of DM/cow per day). Perennial ryegrass-white clover swards appeared to have more herbage removed than allowed due to their PoGSH of less than $4 \mathrm{~cm}$, which led to a higher grazing efficiency compared with PRG-only swards (1.08 vs. 0.97$)$. An average increase in $\mathrm{CP}(34.7 \mathrm{~g} / \mathrm{kg}$ of
DM) occurred between swards with and without white clover (228.3 vs. $193.6 \mathrm{~g} / \mathrm{kg}$ of DM; Table 4). Perennial ryegrass-white clover swards also had a higher OMD content compared with PRG-only swards (796 vs. 776 $\mathrm{g} / \mathrm{kg}$ of DM, respectively) and subsequently lower NDF and ADF contents (441 vs. $401 \mathrm{~g} / \mathrm{kg}$ of DM NDF, and 255 vs. $241 \mathrm{~g} / \mathrm{kg}$ of $\mathrm{DM} \mathrm{ADF}$, respectively), with no differences in ash content.

Concentrate and Silage Supplementation. Concentrate supplementation was similar (344 kg of DM/ cow per year) because cows were fed the same concentrate levels throughout the study. Similar concentrate levels were fed to all treatments in spring, summer, and autumn $(155,73$, and $114 \mathrm{~kg} / \mathrm{cow}$, respectively). However, cows on PRG-white clover swards were fed significantly more silage than cows on PRG-only swards (430 vs. $350 \mathrm{~kg}$ of DM/cow per year; Table 4). This extra silage was primarily fed during the spring in the first 3 yr of the study (additional $109 \mathrm{~kg}$ of DM silage/cow in the first $3 \mathrm{yr}$ with no difference in 2017).

\section{Animal Production}

No interaction between PRG ploidy and white clover inclusion was observed for any of the variables analyzed. Daily milk yield; fat, protein, and lactose content; and MS production did not differ significantly between ploidies (Table 5). Cumulative milk yield and MS yields were not different between ploidy (5,545 vs. $5,495 \mathrm{~kg}$ of milk/cow and 463 vs. $458 \mathrm{~kg}$ of $\mathrm{MS} /$ cow for tetraploid

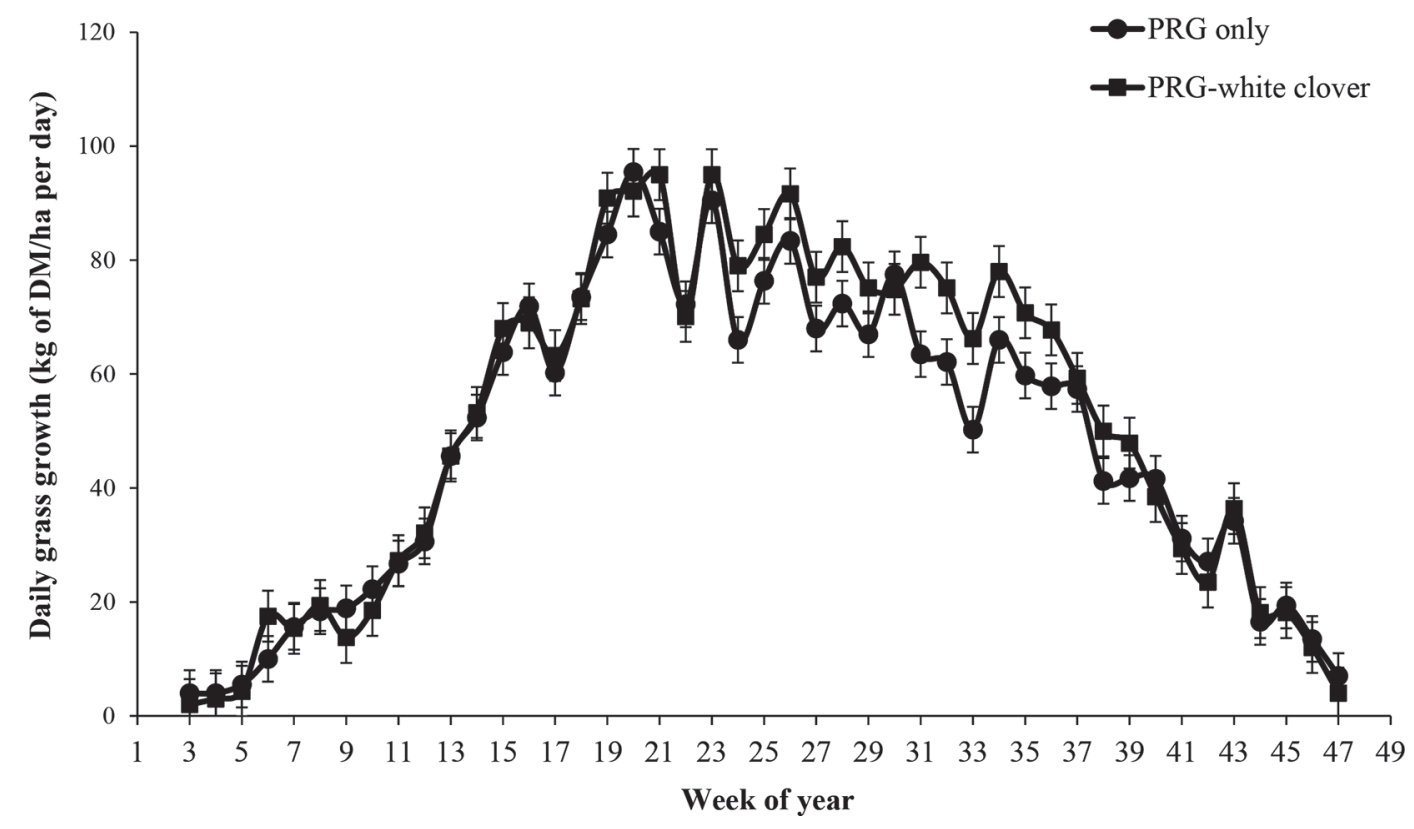

Figure 1. Comparison of perennial ryegrass (PRG)-only (tetraploid and diploid mean) and PRG-white clover (tetraploid and diploid mean) swards for daily grass growth (mean 2014-2017). Error bars represent SE of daily grass growth. 
and diploid, respectively). Daily milk yields and subsequently daily MS yields were higher from PRG-white clover swards compared with PRG-only (20.1 vs. 18.0 $\mathrm{kg} /$ cow and 1.65 vs. $1.49 \mathrm{~kg} /$ cow, respectively). Milk fat content did not differ significantly due to white clover inclusion (Table 5). However, cows grazing PRG-white clover swards had a lower milk protein content compared with those grazing PRG-only (3.85 vs. 3.80\%) and had a significantly higher milk lactose content (4.79 vs. $4.74 \%$ ). Cows grazing PRG-white clover produced an extra $597 \mathrm{~kg}$ of milk/cow per year (5,818 vs. 5,221 $\mathrm{kg}$ of milk/cow) and $48 \mathrm{~kg}$ of MS/cow per year (484 vs. $437 \mathrm{~kg}$ of MS/cow, Figure 3) compared with PRG-only.

On average throughout the $4 \mathrm{yr}$, BW of cows was not affected by grazing swards of either ploidy or whether white clover was present or absent (Table 5). Bodyweight for all grazing treatments was similar at calving and drying off as well as having a similar minimum BW during lactation. Average BW for all grazing treatments was $502 \mathrm{~kg}$ and $\mathrm{BW}$ at calving, minimum BW, and BW at drying off was 517, 461, and $542 \mathrm{~kg}$, respectively. Cow BCS tended to be higher on average throughout the year when grazing tetraploids (2.97) compared with diploids (2.94). The lower BCS from diploid swards was most evident at drying off $(P=0.024)$.

Table 6 shows the responses in milk and MS yield during periods 1,2 , and 3 . No difference in milk and MS yield was observed between ploidies in period 1 or 2 . In period 3, cows grazing tetraploid swards produced more milk (1,316 vs. $1,280 \mathrm{~kg})$ and MS (122 vs. $118 \mathrm{~kg})$ compared with cows grazing diploid swards. White clover inclusion increased milk yield in each period $(+84$ $\mathrm{kg}$ in period 1, $+299 \mathrm{~kg}$ in period 2, and $+207 \mathrm{~kg}$ in period 3), and this response was predominantly from early summer onward, which corresponded to when white clover content started to increase in the sward (Figure 2).

\section{Reproductive Performance}

Reproductive performance was not affected by any of the treatments, and excellent reproductive performance was observed from all grazing treatments. Mean calving date was on average February 5 for all grazing treatments during the $4 \mathrm{yr}$. The average 24-d submission rate was $96 \%$ for all treatments. The 6 -wk pregnancy rate was $86 \%$ on average, with an overall pregnancy rate of $94 \%$ after 12 wk of breeding (Table 7 ).

\section{Performance per Hectare}

All treatments had similar cow grazing days per hectare $(629 \mathrm{~d})$. Similar milk production per hectare $(12,696$ vs. $12,816 \mathrm{~kg} / \mathrm{ha})$ and MS production per hect- 
Table 3. Comparison of perennial ryegrass ploidy and white clover (WC) inclusion on sward nutritive value (mean of 2014-2017)

\begin{tabular}{|c|c|c|c|c|c|c|c|c|}
\hline Item & \multicolumn{4}{|c|}{ Treatment $^{1}$} & $\mathrm{SE}$ & \multicolumn{3}{|c|}{$P$-value } \\
\hline $\mathrm{CP}(\mathrm{g} / \mathrm{kg}$ of $\mathrm{DM})$ & 196 & 192 & 230 & 227 & 2.56 & 0.141 & $<0.001$ & 0.926 \\
\hline $\mathrm{NDF}(\mathrm{g} / \mathrm{kg}$ of DM) & 431 & 451 & 390 & 411 & 3.55 & $<0.001$ & $<0.001$ & 0.958 \\
\hline $\mathrm{ADF}(\mathrm{g} / \mathrm{kg}$ of $\mathrm{DM})$ & 248 & 262 & 233 & 249 & 2.75 & $<0.001$ & $<0.001$ & 0.770 \\
\hline Ash $(\mathrm{g} / \mathrm{kg}$ of $\mathrm{DM})$ & 116 & 122 & 112 & 121 & 2.90 & 0.007 & 0.380 & 0.632 \\
\hline
\end{tabular}

${ }^{1}$ TGO = tetraploid grass only; DGO = diploid grass only; TWC $=$ tetraploid white clover; DWC $=$ diploid white clover.

are $(1,089$ and $1,094 \mathrm{~kg} / \mathrm{ha})$ was observed from tetraploid and diploid swards, respectively. Fat, protein, and lactose yields per hectare were also similar between ploidies, as was the grazed grass, silage, and total grass harvested per hectare in the $4 \mathrm{yr}$ (Table 8 ).

All parameters for milk yield per hectare responded to the inclusion of white clover, with the PRG-white clover treatments supporting an additional $1,954 \mathrm{~kg}$ of milk/ha, $156 \mathrm{~kg}$ of MS/ha, $88 \mathrm{~kg}$ of fat/ha, and $69 \mathrm{~kg}$ of protein/ha (Table 8) compared with the PRG-only treatments. Silage harvested per hectare was not affected by white clover inclusion, but grazed grass harvested $(+656 \mathrm{~kg}$ of $\mathrm{DM} / \mathrm{ha})$ and total grass harvested $(+970 \mathrm{~kg}$ of DM/ha) were significantly increased where white clover was included.

\section{DISCUSSION}

The selection of the correct sward type (i.e., PRG ploidy and cultivar) and whether to include white clover in the sward are 2 important factors influencing the performance of a temperate grazing system. Dineen et al. (2018) reported that when cows grazed PRG-white clover swards, stocking rate and $\mathrm{N}$ fertilizer application were reduced by 0.25 cows $/$ ha and $81 \mathrm{~kg}$ of $\mathrm{N} /$ ha, respectively, compared with when cows grazed PRG-only swards. Therefore, while the negative correlation between $\mathrm{N}$ use and white clover persistence is well reported (Clark and Harris, 1996; Phelan et al., 2013; Chapman et al., 2017), along with the environ- mental impacts of increasing $\mathrm{N}$ inputs (Ledgard et al., 2009), the effect of white clover with relatively high $\mathrm{N}$ inputs on the productivity of grass-based production systems should be examined. To achieve this objective, we compared PRG-white clover swards with PRG-only swards at the same stocking rate $(2.75$ cows/ha) and $\mathrm{N}$ fertilizer rate $(250 \mathrm{~kg} / \mathrm{ha})$, which is the limit for $\mathrm{N}$ fertilizer application in Ireland set under the European Union Nitrates directive.

\section{Sward Productivity and Use}

Although we detected no effect of PRG ploidy on total or seasonal herbage DM production, the literature contains contrasting reports as to whether tetraploids or diploids are higher yielding. Balocchi and López (2009) showed that diploid swards had greater herbage DM production compared with tetraploid swards under grazing, while Burns et al. (2013) showed that tetraploid cultivars out-yielded diploid cultivars in plots under a simulated conservation management strategy.. Previous research has shown certain cultivars are more suited to a cutting system than a grazing system (Gilliland et al., 2002). Within this study, the combination of grazing management along with silage conservation across all treatments may have negated any effect ploidy might have had on annual herbage DM production.

As reported previously by Guy et al. (2018b), who used the same platform during the same 4-yr period, PRG-white clover swards had higher DM yields com-

Table 4. Comparison of perennial ryegrass ploidy and white clover (WC) inclusion on silage supplementation for lactating cows during spring, summer, and autumn (mean of 2014-2017)

\begin{tabular}{|c|c|c|c|c|c|c|c|c|}
\hline \multirow{2}{*}{$\begin{array}{l}\text { Silage supplementation } \\
\text { (kg of } \mathrm{DM} / \mathrm{cow})\end{array}$} & \multicolumn{4}{|c|}{ Treatment $^{2}$} & \multirow[b]{2}{*}{$\mathrm{SE}$} & \multicolumn{3}{|c|}{$P$-value } \\
\hline & TGO & DGO & TWC & DWC & & Ploidy & WC & Ploidy $\times$ WC \\
\hline Spring & 170 & 167 & 242 & 245 & 2.62 & 0.810 & $<0.001$ & 0.273 \\
\hline Summer & 42 & 19 & 9 & 7 & 0.52 & $<0.001$ & $<0.001$ & $<0.001$ \\
\hline Autumn & 148 & 152 & 161 & 195 & 6.93 & 0.006 & $<0.001$ & 0.028 \\
\hline
\end{tabular}

${ }^{1}$ Spring = January 1-April 7; summer = April 8-August 31; autumn = September 1-December 31.

${ }^{2} \mathrm{TGO}=$ tetraploid grass only; DGO = diploid grass only; TWC $=$ tetraploid white clover; DWC $=$ diploid white clover. 


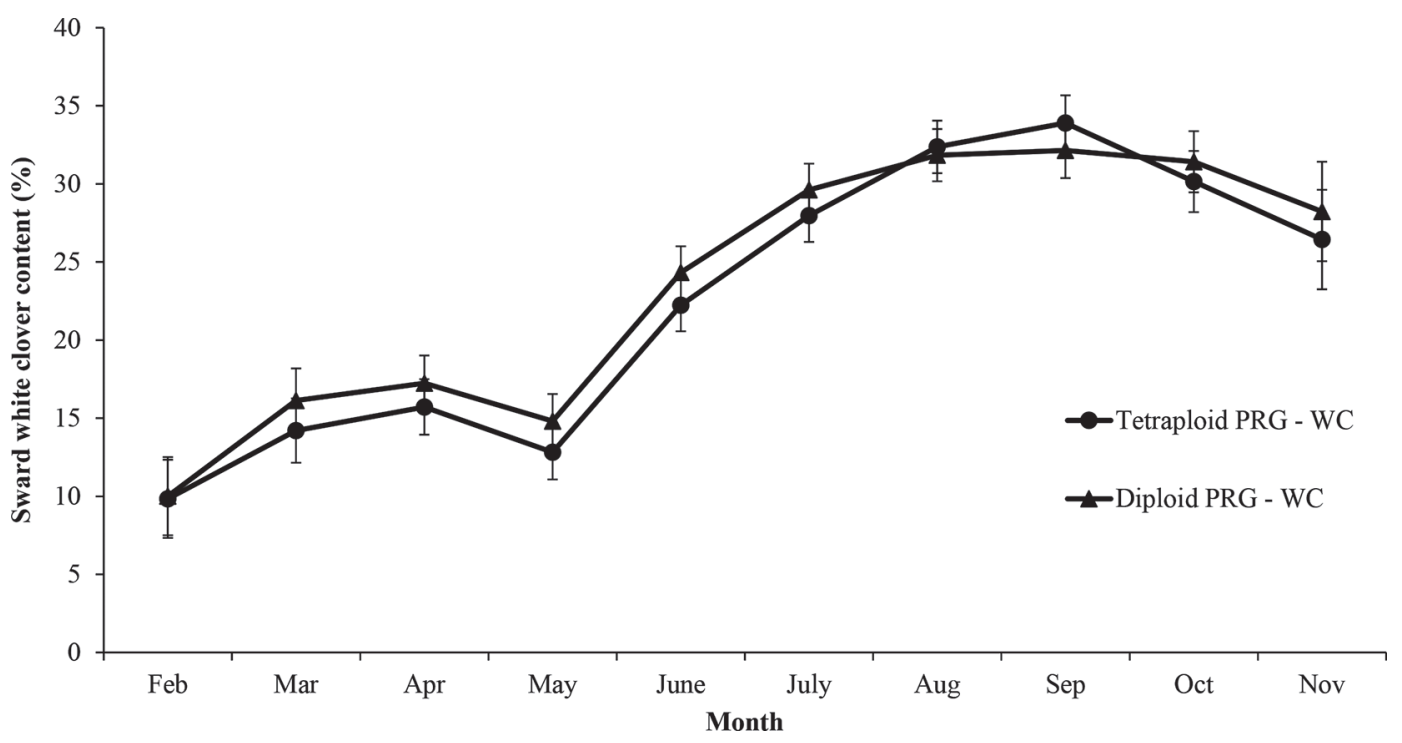

Figure 2. Sward white clover content for tetraploid perennial ryegrass (PRG)-white clover (WC) and diploid PRG-WC swards (2014-2017). Error bars represent SE of monthly white clover content.

pared with PRG-only swards. This finding is in contrast to previous research, in which white clover inclusion had no effect on annual herbage DM production (Egan et al., 2018; Enriquez-Hidalgo et al., 2014) or reduced herbage DM production (Humphreys et al., 2009). However, in most of these experiments, chemical $\mathrm{N}$ use was reduced to promote biological $\mathrm{N}$ fixation from white clover. White clover has been reported to be able to biologically fix up to $200 \mathrm{~kg} \mathrm{~N} /$ ha (Ledgard, 2001; Carlsson and Huss-Danell, 2003), although at lower chemical $\mathrm{N}$ fertilization rates than in this study.
Despite the high level of $\mathrm{N}$ fertilizer used in this study $(250 \mathrm{~kg} \mathrm{~N} / \mathrm{ha})$, within a subset of paddocks used in this experiment, Guy et al. (2018a) reported a calculated biological $\mathrm{N}$ fixation of $151 \mathrm{~kg} \mathrm{~N} /$ ha. That report demonstrates the potential to retain $\mathrm{N}$ fixation even at high applied $\mathrm{N}$ levels, which would explain the observed higher growth rates (Figure 1) throughout summer and autumn and the extra $1,205 \mathrm{~kg}$ of $\mathrm{DM} /$ ha produced on PRG-white clover swards compared with PRG-only swards. This finding indicates that the benefits of white clover were being gained despite the high $\mathrm{N}$ fertilizer

Table 5. Effect of perennial ryegrass ploidy and white clover (WC) inclusion on milk production and composition, BW, and BCS (mean of 2014-2017)

\begin{tabular}{|c|c|c|c|c|c|c|c|c|}
\hline Item & \multicolumn{4}{|c|}{ Treatment $^{1}$} & $\mathrm{SE}$ & \multicolumn{3}{|c|}{$P$-value } \\
\hline Daily milk yield $(\mathrm{kg})$ & 18.0 & 18.0 & 20.2 & 19.9 & 0.16 & 0.270 & $<0.001$ & 0.386 \\
\hline Milk protein (\%) & 3.87 & 3.83 & 3.79 & 3.80 & 0.017 & 0.362 & 0.002 & 0.163 \\
\hline Milk lactose (\%) & 4.75 & 4.73 & 4.78 & 4.79 & 0.010 & 0.544 & $<0.001$ & 0.115 \\
\hline Daily milk solids ${ }^{2}(\mathrm{~kg})$ & 1.49 & 1.48 & 1.66 & 1.64 & 0.012 & 0.150 & $<0.001$ & 0.733 \\
\hline Average BW (kg) & 506 & 493 & 503 & 507 & 3.8 & 0.226 & 0.146 & 0.020 \\
\hline BW at calving & 516 & 514 & 516 & 521 & 5.5 & 0.685 & 0.536 & 0.502 \\
\hline Minimum BW during lactation & 468 & 454 & 460 & 462 & 3.7 & 0.101 & 0.896 & 0.031 \\
\hline BW at drying off & 549 & 533 & 539 & 548 & 4.4 & 0.430 & 0.652 & 0.005 \\
\hline Average BCS & 2.98 & 2.92 & 2.96 & 2.96 & 0.012 & 0.030 & 0.536 & 0.022 \\
\hline BCS at calving & 3.16 & 3.16 & 3.14 & 3.17 & 0.017 & 0.460 & 0.594 & 0.415 \\
\hline Minimum BCS during lactation & 2.77 & 2.71 & 2.75 & 2.75 & 0.015 & 0.043 & 0.519 & 0.028 \\
\hline
\end{tabular}

${ }^{1}$ TGO $=$ tetraploid grass only; DGO = diploid grass only; TWC $=$ tetraploid white clover; DWC $=$ diploid white clover.

${ }^{2}$ Milk solids $=\mathrm{kg}$ of fat + protein. 


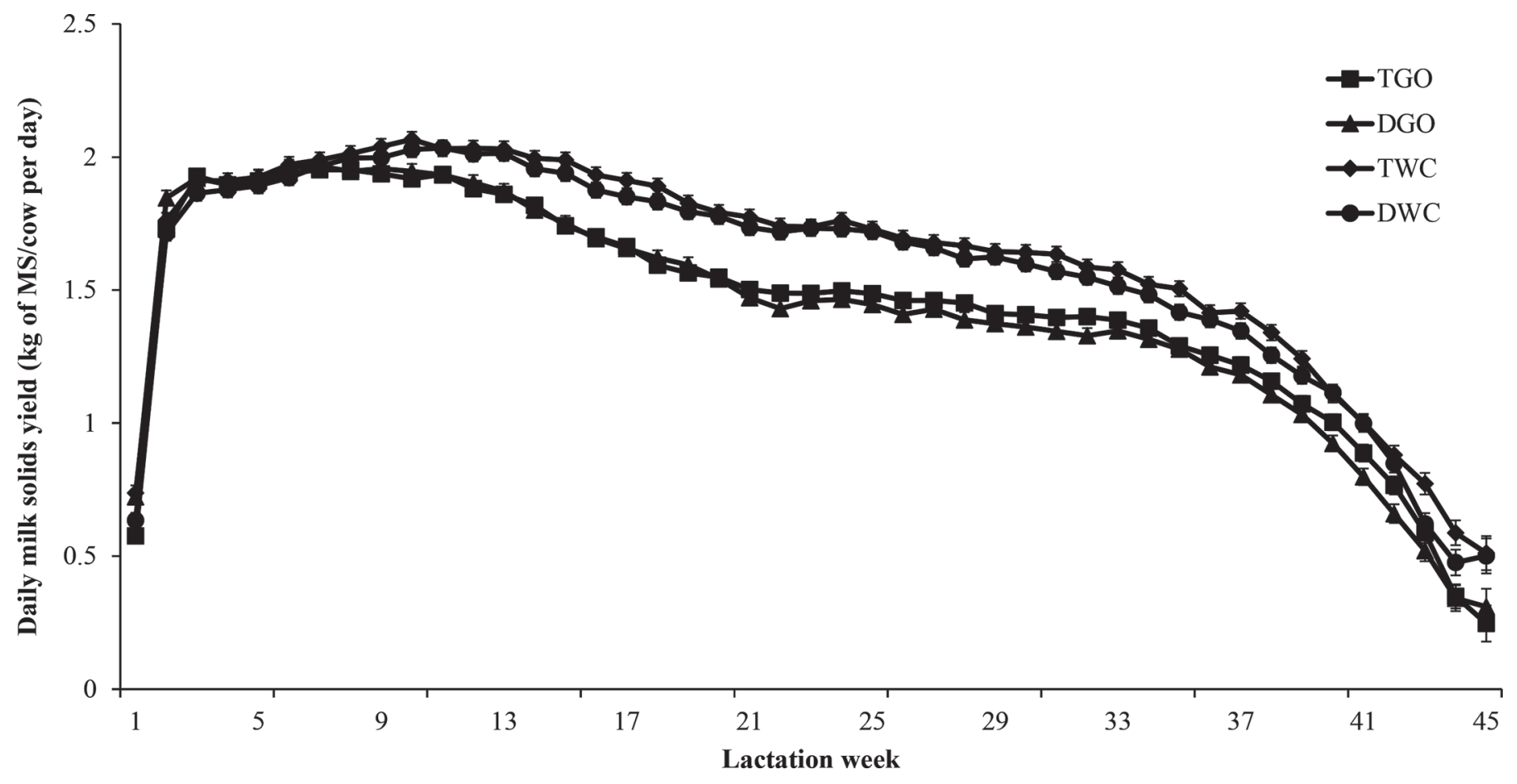

Figure 3. Daily milk solids (MS) yield per cow by lactation week for tetraploid perennial ryegrass (PRG)-only (TGO), diploid PRG-only (DGO), tetraploid PRG-white clover (TWC), and diploid PRG-white clover (DWC; mean of 2014-2017). Error bars represent SE of daily milk solids yield.

regimen imposed. However, the extra herbage produced may not have used the extra $\mathrm{N}$ supplied by biological $\mathrm{N}$ fixation, and the potential loss of surplus $\mathrm{N}$ on highly stocked farms, combined with high levels of artificial N fertilizer, is an environmental concern that needs to be considered. A recent review concluded that $\mathrm{N}$ leaching does not differ when $\mathrm{N}$ is supplied by either biological $\mathrm{N}$ fixation or by artificial $\mathrm{N}$; therefore, nitrate leaching rates should be calculated using total $\mathrm{N}$ in the system and not just artificial N (Chapman et al., 2018). The white clover content of swards and the amount of artificial $\mathrm{N}$ applied has been shown to affect the amount of biological $\mathrm{N}$ fixation that can occur in the sward (Elgersma et al., 1998; Humphreys et al., 2008). On average throughout the 4 -yr period, the white clover content was $23.1 \%$ despite the high $\mathrm{N}$ application rate. Furthermore, white clover content did not differ between ploidies, averaging 22.6 and $23.6 \%$ for TWC swards and DWC swards, respectively. Both TWC and DWC had similar pre- and postgrazing sward heights

Table 6. Effect of perennial ryegrass ploidy and white clover (WC) inclusion on milk and milk solids production in periods 1,2 , and 3 of lactation (mean of 2014-2017)

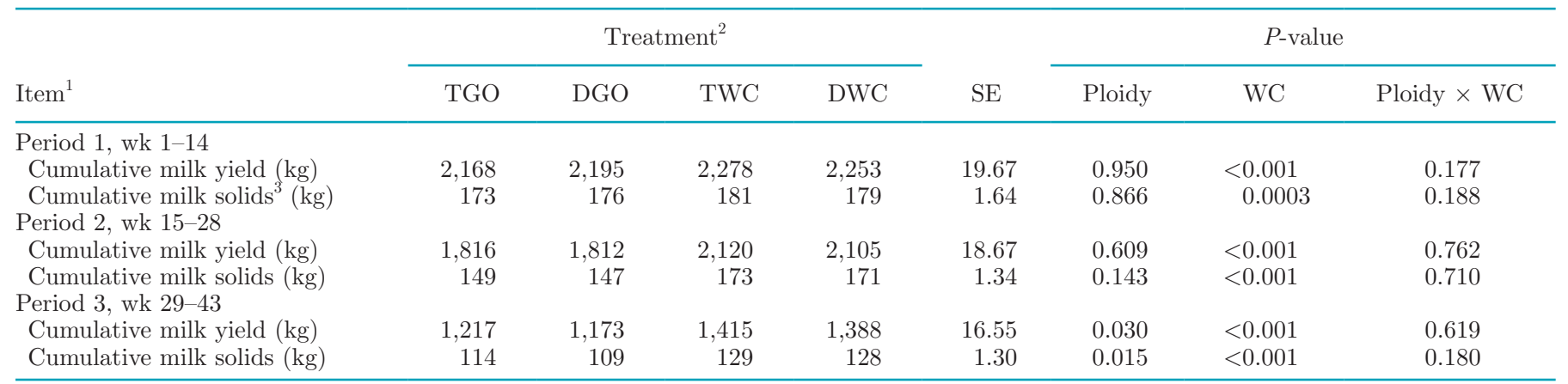

${ }^{1}$ Period 1 = wk 1-14 of lactation; period $2=$ wk 15-28 of lactation; period $3=$ wk 29-42 of lactation.

${ }^{2} \mathrm{TGO}=$ tetraploid grass only, DGO $=$ diploid grass only, TWC $=$ tetraploid white clover, DWC $=$ diploid white clover.

${ }^{3}$ Milk solids $=\mathrm{kg}$ of fat + protein. 
Table 7. Effect of perennial ryegrass ploidy and white clover (WC) inclusion on reproductive performance (mean of 2014-2017)

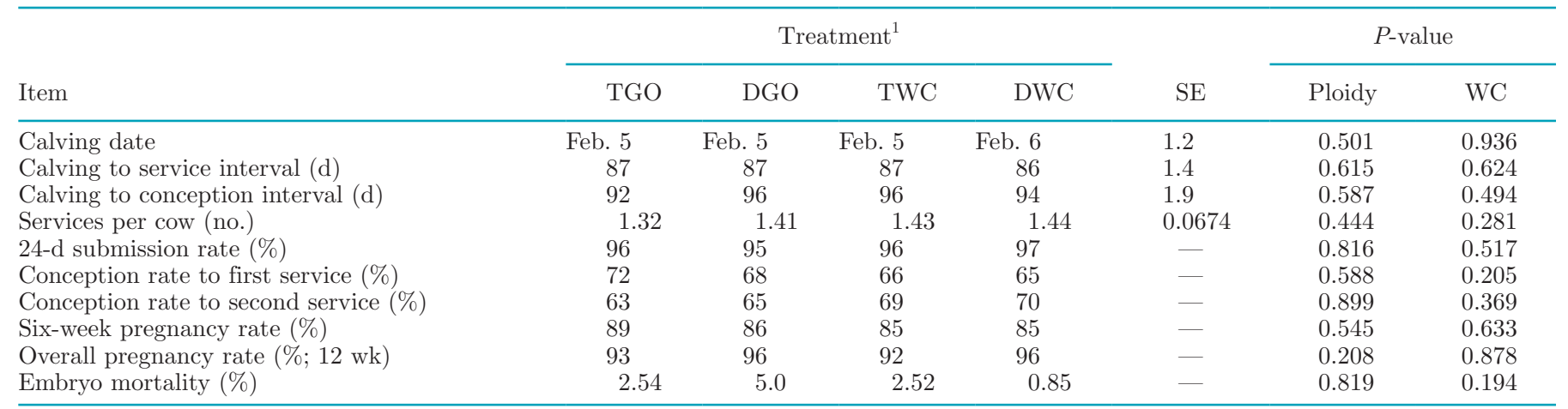

${ }^{1}$ TGO $=$ tetraploid grass only; DGO = diploid grass only; TWC $=$ tetraploid white clover; DWC $=$ diploid white clover.

throughout the grazing season, which reduced the competition for light between PRG and white clover and therefore negated any sward structure effects between PRG ploidies.

Similar to previous research (Gowan et al., 2003; Wims et al., 2013), our study found diploid swards to have a higher PrGHM than tetraploid swards. The lower PoGSH of tetraploids compared with diploids was previously observed by Wims et al. (2013). This finding is associated with the high leaf-to-stem ratio and higher energy content of tetraploids, which can increase grazing efficiency (Balocchi and López, 2009). In addition, other studies have shown that cows have a preference for grazing tetraploid over diploid cultivars, which was associated with a longer grazing time, lower PoGSH, and higher digestibility of the tetraploid cultivars (Smith et al., 2001; Stilmant et al., 2005).

In the current study, PRG-white clover swards had significantly lower PrGHM than the PRG-only swards, which was similar to previous studies (Schils et al., 2000b; Ribeiro Filho et al., 2005), although Egan et al. (2018) found no significant differences in PrGHM across the grazing season. Similar to this study, Egan et al. (2018) reported lower PrGHM in rotation 1 in spring due to lower winter growth rates from PRG-white clover swards, but this was not reflected throughout the remainder of the year. The lower PrGHM in spring was due to the lower overwinter herbage growth rate, which is a characteristic difference between PRG-white clover swards and PRG-only swards, as reported by Lüscher et al. (2001) and Guy (2018). Overwinter growth (growth in December and January) in this study was 3.5 and $6.3 \mathrm{~kg}$ of $\mathrm{DM} / \mathrm{d}$ for PRG-white clover and PRG-only swards on average over the experimental period. This led to a lower opening average farm cover in spring, reduced herbage availability, and lower daily herbage allowance for PRG-white clover treatments compared with PRG-only treatments. As a consequence, increased supplement, in the form of baled silage, was required for cows grazing the PRG-white clover swards in spring (Table 4). This additional silage fed $(+80 \mathrm{~kg}$ of $\mathrm{DM} /$ cow per year) was produced within each treatment, as an additional $114 \mathrm{~kg}$ of DM of silage per cow per year was harvested from PRG-white clover swards. Although harvested silage was not significantly different between treatments, it did cover the additional silage required

Table 8. Effect of perennial ryegrass ploidy and white clover (WC) inclusion on milk production per hectare from grazing and grass harvested per hectare (mean of 2014-2017)

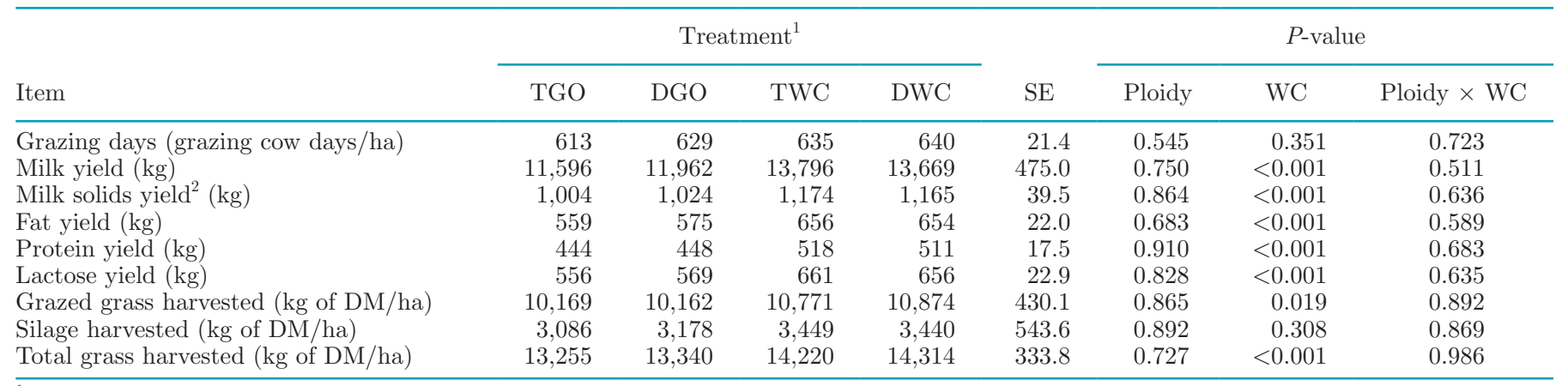

${ }^{1} \mathrm{TGO}=$ tetraploid grass only; DGO = diploid grass only; TWC $=$ tetraploid white clover; DWC $=$ diploid white clover.

${ }^{2}$ Milk solids $=\mathrm{kg}$ of fat + protein. 
in PRG-white clover treatments in spring. However, increased supplementation leads to increased production costs, which must be minimized in low-cost grazing systems (Dillon et al., 2005).

The observation that including white clover significantly lowered the PoGSH is corroborated by previous studies that showed cows actively selecting white clover over PRG in swards (Rutter et al., 2002, 2004; Cosgrove et al., 2006). Several studies have shown that cow preference for white clover is the determining factor in lower PoGSH (Phillips and James, 1998; Ribeiro Filho et al., 2005), and it has been hypothesized that this outcome is due to the prehensibility of the mixed forage and a higher OMD content in white clover swards. The expected overall effect would be a lower resistance to chewing and subsequently a higher passage rate of forage through the rumen (Søegaard, 1993; EnriquezHidalgo et al., 2018).

\section{Animal Production}

In this 4-yr study, the daily or total milk yield did not differ between cows grazing either ploidy. Tetraploid PRG-only and DGO swards were managed similarly, and although DGO had a higher PrGHM and subsequent daily herbage allowance, herbage removed was similar. Although the differences observed between TGO and DGO in terms of sward nutritive value were significant, they were biologically small; therefore, the lack of ploidy effect on milk yield was unsurprising. Evidence of the effect of ploidy on milk production per cow is conflicting, with some studies showing increased milk yield for cows grazing tetraploid compared with diploid swards (Castle and Watson, 1971; Lantinga and Groot, 1996; Wims et al., 2013), whereas other studies have shown no difference in production between cows grazing different ploidies (Gowen et al., 2003; O'Donovan and Delaby, 2005). Gowen et al. (2003) reported no overall difference in milk yield between ploidy groups; however, cows grazing 1 tetraploid cultivar produced more milk than cows grazing the other 3 cultivars. This outcome may indicate that variations between individual cultivars can be greater than between ploidies (Tubritt et al., 2018) and that the beneficial effects of individual cultivars may only be seasonally expressed (Wims et al., 2013). This possibility is supported by the fact that in period 3, which corresponded to late lactation and autumn, cows grazing tetraploid swards produced more milk and MS than those grazing diploid swards.

The observed significant increase in daily milk yield and MS yield when cows grazed PRG-white clover swards compared with PRG-only swards agrees with numerous previous studies (Schils et al., 2000a; Ribeiro
Filho et al., 2003). These studies observed varying increases in milk production from PRG-white clover swards at artificial $\mathrm{N}$ application rates $(90-150 \mathrm{~kg}$ of $\mathrm{N} /$ ha) lower than those of the current study. Egan et al. (2018) studied milk production from cows grazing PRG-white clover receiving 150 or $250 \mathrm{~kg}$ of $\mathrm{N} / \mathrm{ha}$ and PRG-only swards receiving $250 \mathrm{~kg}$ of N/ha. They found that cows grazing either of the PRG-white clover swards produced more milk $(+214 \mathrm{~kg} /$ cow per year $)$ and MS $(+34 \mathrm{~kg} / \mathrm{cow}$ per year) compared with PRGonly swards.

The difference in milk production from the PRGwhite clover swards was observed from May onwards in each year (Figure 3). This pattern is consistent with white clover content in the sward increasing as the season progresses (Figure 2) and is similar to other studies (Schils et al., 2000a; Woodward et al., 2001). The increase in milk production is typically based on 2 factors: an increase in DM intake and an increase in herbage nutritive value in PRG-white clover swards compared with PRG-only swards. In this study herbage removed (an estimate of grass eaten per cow) was $0.8 \mathrm{~kg} /$ cow per day greater for cows grazing PRG-white clover swards versus PRG-only swards over the grazing season. This outcome was due to the lower PoGSH associated with PRG-white clover swards because herbage allowance was similar for all grazing treatments (Table 2). Ribeiro Filho et al. (2005) reported a $1.5 \mathrm{~kg} / \mathrm{d}$ increase in DMI for cows grazing PRG-white clover swards compared with PRG-only swards, and Egan et al. (2017) reported an $8 \%$ increase in DMI in July when sward white clover content was highest. Andrews et al. (2007) suggested that a sward white clover content greater than $20 \%$ is required to see an animal production response. Our study is in agreement because herbage removed was greater in summer and autumn, when sward white clover content was greatest, with no difference in herbage removed in spring, when sward white clover content was lower (Figure 2). When total feed intake per cow (grazed grass, concentrate, and silage supplementation) during lactation is calculated, PRG-white clover cows consumed $320 \mathrm{~kg}$ more DM than PRG-only cows (4,709 vs. $4,389 \mathrm{~kg}$ of $\mathrm{DM} /$ cow, respectively). Using a milk production response of $9.7 \mathrm{~kg}$ of DM consumed per $\mathrm{kg}$ of MS produced (4,709 $\mathrm{kg}$ of DM eaten/cow divided by $485 \mathrm{~kg}$ of $\mathrm{MS} / \mathrm{cow}$ ), we can calculate that $32 \mathrm{~kg}$ MS, or $68 \%$ of the increase in MS produced, was due to increased DMI, with the remaining $32 \%$ likely due to the increase in sward nutritive value and associated benefits such as the faster breakdown and passage of white clover through the rumen Minson (1990). White clover inclusion increased sward OMD and CP content and reduced NDF content similar to reports by Ribeiro Filho et al. (2003) and Enriquez-Hidalgo et al. (2018). 
Previous studies have indicated increases of up to $40 \mathrm{~g} /$ $\mathrm{kg}$ DM of CP content compared with PRG-only swards (Cosgrove et al., 2006; Rodriguez, 2016; EnriquezHidalgo et al., 2018), which is similar to the increase observed in this study. The reduced NDF content of the PRG-white clover swards could also be a factor contributing to the increased milk production associated with PRG-white clover swards because the rate and extent of NDF digestion in the rumen can have a major effect on the energy available from forage (Oba and Allen, 1999).

In spring-calving grass-based systems, calving cows compactly to match grass production with herd demand is critical to farm profitability (Shalloo et al., 2014). In this study, the overall level of reproductive performance was high and is reflective of excellent reproductive management and the use of high-EBI animals (Berry et al., 2005). Ploidy or white clover inclusion had no effect on reproductive performance, which also corresponds to similar BW and BW loss during lactation from all treatments. This outcome indicates that all treatments were managed similarly. Although ploidy had a significant effect on several BCS variables, the differences in BCS were biologically small and subsequently had no impact on reproductive performance. Cows grazing PRG-white clover swards did not have lower BCS despite the increase in milk production, indicating that the increase was not due to greater mobilization of body reserves.

\section{Performance per Hectare}

Milk production per hectare is an important indicator of the efficiency of grazing systems when land availability and accessibility can be a major limiting factor. Previous studies have shown milk production per hectare to increase linearly with stocking rate (Macdonald et al., 2008; McCarthy et al., 2013). Stocking rates in grass-based systems are typically a reflection of a farm's ability to grow and use the correct amount of herbage to match the demand of it stock. In this study, all grazing treatments were stocked at 2.75 cows/ha; therefore, as individual animal performance varied, production per hectare subsequently also varied. In this case, the PRG-white clover swards produced 1,205 kg of DM/ha and used $970 \mathrm{~kg}$ of DM/ha more herbage than PRGonly swards. This increase in grazed grass used is the main reason for the increase in milk production per hectare for PRG-white clover treatments. However, as the bulk of this additional herbage production grew in summer when herbage growth rates were already exceeding animal demands, the benefits were largely captured as silage; consequently, managing higher stocking rates could prove difficult in the spring and autumn.
This link between grazed grass used and farm profitability has recently been reported, suggesting a further advantage for PRG-white clover swards compared with PRG-only (Hanrahan et al., 2018). Furthermore, grazed forage is the cheapest form of feed for dairy cows (Dillon et al., 2005); therefore, increasing milk production from grazed forage can lower costs and possibly increase profitability. Ultimately, farm profitability mainly relies on milk production per cow, stocking rate, and pasture use, so the higher milk production and pasture use with the PRG-white clover grazing swards even under a high $\mathrm{N}$ regimen should be more profitable than PRG-only swards. Further analysis is required to measure the financial costs and benefits for a farm business using PRG-white clover swards.

\section{CONCLUSIONS}

Grazing either tetraploid or diploid swards had no overall significant effect on dairy cow milk production, but the inclusion of white clover with either ploidy significantly increased milk and MS production by $597 \mathrm{~kg}$ of milk/cow per year and $48 \mathrm{~kg}$ of $\mathrm{MS} / \mathrm{cow}$ per year. This outcome indicates the potential to use white clover in high-N grazing dairy systems to increase milk production. With an additional 1,205 kg/ha of herbage DM also produced per year, it was possible to conserve more herbage to supplement for the lower overwinter growth rate of the PRG-white clover swards. These results indicate the potential benefits of using white clover in grazing dairy systems and also the practical implications of such a system. However, the environmental implications of using white clover in a high-N application system need to be investigated further.

\section{ACKNOWLEDGMENTS}

This research was funded by the Irish Dairy Levy administered by Dairy Research Ireland. The first author was in receipt of a Teagasc Walsh Fellowship. The authors gratefully acknowledge the invaluable assistance of the farm and technical staff based at Teagasc Clonakilty and Teagasc Moorepark.

\section{REFERENCES}

Andrews, M., D. Scholefield, M. Abberton, B. A. McKenzie, S. Hodge, and J. A. Raven. 2007. Use of white clover as an alternative to nitrogen fertiliser for dairy pastures in nitrate vulnerable zones in the UK: Productivity, environmental impact and economic considerations. Ann. Appl. Biol. 151:11-23.

Association of Official Analytical Chemists. 1990. Pages 777-800 in Official Methods of Analysis. Vol. 2. Association of Official Analytical Chemists, Arlington, VA.

Balocchi, O. A., and I. F. López. 2009. Herbage production, nutritive value and grazing preference of diploid and tetraploid peren- 
nial ryegrass cultivars (Lolium perenne L.). Chil. J. Agric. Res. 69:331-339.

Berry, D. P., L. Shalloo, A. R. Cromie, V. E. Olori, and P. Amer. 2005. Economic breeding index for dairy cattle in Ireland. Technical report to the Irish Cattle Breeding Federation. Accessed Jun. 25, 2019. https://www.icbf.com/wp/wp-content/uploads/2013/ 06/ICBF_Jan05_EBIreport.pdf.

Burns, G., T. Gilliland, D. Grogan, S. Watson, and P. O'Kiely. 2013. Assessment of herbage yield and quality traits of perennial ryegrasses from a national variety evaluation scheme. J. Agric. Sci. 151:331-346.

Carlsson, G., and K. Huss-Danell. 2003. Nitrogen fixation in perennial forage legumes in the field. Plant Soil 253:353-372.

Castle, M., and J. Watson. 1971. A comparison between a diploid and a tetraploid ryegrass for milk production. J. Agric. Sci. 77:69-76.

Chapman, D., J. Lee, L. Rossi, G. Edwards, J. Pinxterhuis, and E. Minnee. 2017. White clover: The forgotten component of highproducing pastures? Anim. Prod. Sci. 57:1269-1276.

Chapman, D., I. Pinxterhuis, S. Ledgard, and T. Parsons. 2018. White clover or nitrogen fertiliser for dairying under nitrate leaching limits? Anim. Prod. Sci. https://doi.org/10.1071/AN18577.

Clark, D., and S. Harris. 1996. White clover or nitrogen fertiliser for dairying? Pages 107-114 in White Clover: New Zealand's Competitive Edge. Grassland Research and Practice Series No. 6. D. R. Woodfield, ed. New Zealand Grassland Association, Palmerston North, New Zealand.

Cosgrove, G., J. Burke, A. Death, G. Lane, K. Fraser, and D. Pacheco, 2006. The effect of clover-rich diets on cows in mid lactation: Production, behaviour and nutrient use. Proc. N.Z. Grassl. Assoc. 68:267-273.

Delaby, L., J. Pavie, B. McCarthy, E. A. Comeron, and J. L. Peyraud. 2016. Les légumineuses fourragères, indispensables à l'élevage de demain. Fourrages (Versailles) 226:77-86.

Dillon, P., J. R. Roche, L. Shalloo, and B. Horan. 2005. Optimising financial return from grazing in temperate pastures. Utilisation of grazed grass in temperate animal systems. Pages 131-147 in Proceedings of a Satellite Workshop of the XXth Int. Grassl. Congr. J. J. Murphy, ed. Wageningen Academic Publishers, Wageningen, the Netherlands.

Dineen, M., L. Delaby, T. Gilliland, and B. McCarthy. 2018. Metaanalysis of the effect of white clover inclusion in perennial ryegrass swards on milk production. J. Dairy Sci. 101:1804-1816.

Edmonson, A. J., I. J. Lean, L. D. Weaver, T. Farver, and G. Webster 1989. A body condition scoring chart for Holstein dairy cows. J. Dairy Sci. 72:68-78.

Egan, M., N. Galvin, and D. Hennessy. 2018. Incorporating white clover (Trifolium repens L.) into perennial ryegrass (Lolium perenne L.) swards receiving varying levels of nitrogen fertilizer: Effects on milk and herbage production. J. Dairy Sci. 101:3412-3427.

Egan, M., M. Lynch, and D. Hennessy. 2017. Including white clover in nitrogen fertilized perennial ryegrass swards: Effects on dry matter intake and milk production of spring calving dairy cows. J. Agric. Sci. 155:657-668.

Elgersma, A., M. Nassiri, and H. Schlepers. 1998. Competition in perennial ryegrass-white clover mixtures under cutting. 1. Dry-matter yield, species composition and nitrogen fixation. Grass Forage Sci. 53:353-366.

Enriquez-Hidalgo, D., T. Gilliland, M. Deighton, M. O'Donovan, and D. Hennessy. 2014. Milk production and enteric methane emissions by dairy cows grazing fertilized perennial ryegrass pasture with or without inclusion of white clover. J. Dairy Sci. 97:1400-1412.

Enriquez-Hidalgo, D., T. Gilliland, M. Egan, and D. Hennessy. 2018. Production and quality benefits of white clover inclusion into ryegrass swards at different nitrogen fertilizer rates. J. Agric. Sci. 156:378-386

Finneran, E., P. Crosson, P. O'Kiely, L. Shalloo, D. Forristal, and M. Wallace. 2012. Stochastic simulation of the cost of home-produced feeds for ruminant livestock systems. J. Agric. Sci. 150:123-139.

Gilliland, T., P. Barrett, R. Mann, R. Agnew, and A. Fearon. 2002. Canopy morphology and nutritional quality traits as potential grazing value indicators for Lolium perenne varieties. J. Agric. Sci 139:257-273.

Gooding, R. F., J. Frame, and C. Thomas. 1996. Effects of sward type and rest periods from sheep grazing on white clover presence in perennial ryegrass/white clover associations. Grass Forage Sci. $51: 180-189$

Gowen, N., M. O'Donovan, I. Casey, M. Rath, L. Delaby, and G Stakelum. 2003. The effect of grass cultivars differing in heading date and ploidy on the performance and dry matter intake of spring calving dairy cows at pasture. Anim. Res. 52:321-336.

Guy, C. 2018. Impact of Lolium perenne L. ploidy and Trifolium repens L. inclusion on sward structural characteristics, morphology and nutritive value in grazing swards. PhD Diss. Queen's University Belfast, Belfast, Northern Ireland.

Guy, C., D. Hennessy, T. J. Gilliland, F. Coughlan, and B. McCarthy. 2018a. Growth, morphology and biological nitrogen fixation potential of perennial ryegrass-white clover swards throughout the grazing season. J. Agric. Sci. 156:188-199.

Guy, C., D. Hennessy, T. J. Gilliland, F. Coughlan, B. McClearn, M. Dineen, and B. McCarthy. 2018b. Comparison of perennial ryegrass, Lolium perenne L., ploidy and white clover, Trifolium repens L., inclusion for herbage production, utilization and nutritive value. Grass Forage Sci. 73:865-877.

Hanrahan, L., A. Geoghegan, M. O'Donovan, V. Griffith, E. Ruelle, M. Wallace, and L. Shalloo. 2017. PastureBase Ireland: A grassland decision support system and national database. Comput. Electron. Agric. 136:193-201.

Hanrahan, L., N. McHugh, T. Hennessy, B. Moran, R. Kearney, M. Wallace, and L. Shalloo. 2018. Factors associated with profitability in pasture-based systems of milk production. J. Dairy Sci. 101:5474-5485.

Humphreys, J., I. Casey, and A. Laidlaw. 2009. Comparison of milk production from clover-based and fertilizer-N-based grassland on a clay-loam soil under moist temperate climatic conditions. Ir. J. Agric. Food Res. 48:189-207.

Humphreys, J., K. O'Connell, and I. Casey. 2008. Nitrogen flows and balances in four grassland-based systems of dairy production on a clay-loam soil in a moist temperate climate. Grass Forage Sci. 63:467-480.

Kennedy, E., M. McEvoy, J. Murphy, and M. O’Donovan. 2009. Effect of restricted access time to pasture on dairy cow milk production, grazing behavior, and dry matter intake. J. Dairy Sci. 92:168-176.

Lantinga, E. A., and J. C. Groot. 1996. Optimization of grassland production and herbage feed quality in an ecological context. Pages 58-66 in Utilization of Local Feed Resources by Dairy Cattle. EAAP Publication No. 84. A. F. Groen and J. van Bruchem, eds. Wageningen Press, Wageningen, the Netherlands.

Ledgard, S., R. Schils, J. Eriksen, and J. Luo. 2009. Environmental impacts of grazed clover/grass pastures. Ir. J. Agric. Food Res. 48:209-226.

Ledgard, S. F. 2001. Nitrogen cycling in low input legume-based agriculture, with emphasis on legume/grass pastures. Plant Soil 228:43-59

Lüscher, A., I. Mueller-Harvey, J. F. Soussana, R. M. Rees, and J. L. Peyraud. 2014. Potential of legume-based grassland-livestock systems in Europe: A review. Grass Forage Sci. 69:206-228.

Lüscher, A., B. Staheli, R. Braun, and J. Nosberger. 2001. Leaf area, competition with grass, and clover cultivar: Key factors to successful overwintering and fast regrowth of white clover (Trifolium repens L.) in spring. Ann. Bot. (Lond.) 88:725-735.

Macdonald, K., C. Glassey, and R. Rawnsley. 2010. The emergence, development and effectiveness of decision rules for pasture based dairy systems. Pages 199-209 in Proceedings of the 4th Australasian Dairy Science Symposium, Lincoln, New Zealand. Meeting the Challenges for Pasture-Based Dairying. G. R. Edwards and R. H. Bryant, ed. Lincoln University, NZ.

Macdonald, K. A., J. W. Penno, J. A. Lancaster, and J. R. Roche 2008. Effect of stocking rate on pasture production, milk production, and reproduction of dairy cows in pasture-based systems. J. Dairy Sci. 91:2151-2163. 
McCarthy, B., L. Delaby, K. Pierce, A. Brennan, and B. Horan. 2013. The effect of stocking rate and calving date on milk production of Holstein-Friesian dairy cows. Livest. Sci. 153:123-134.

McGilloway, D. A. 2005. Grassland: A Global Resource. Wageningen Academic Publ., Wageningen, the Netherlands.

Minson, D. 1990. Forage in Ruminant Production. Academic Press, San Diego, CA.

Morgan, D., G. Stakelum, and J. Dwyer. 1989. Modified neutral detergent cellulase digestibility procedure for use with the 'Fibertec' system. Isr. J. Agric. Res. 28:91-92.

O'Donovan, M., and L. Delaby. 2005. A comparison of perennial ryegrass cultivars differing in heading date and grass ploidy with spring calving dairy cows grazed at two different stocking rates. Anim. Res. 54:337-350.

O'Donovan, M., E. Lewis, and P. O'Kiely. 2011. Requirements of future grass-based ruminant production systems in Ireland. Ir. J. Agric. Food Res. 50:1-21.

Oba, M., and M. Allen. 1999. Evaluation of the importance of the digestibility of neutral detergent fiber from forage: Effects on dry matter intake and milk yield of dairy cows. J. Dairy Sci. 82:589 596.

Phelan, P., I. Casey, and J. Humphreys. 2013. The effect of target postgrazing height on sward clover content, herbage yield, and dairy production from grass-white clover pasture. J. Dairy Sci. 96:1598-1611.

Phillips, C. J. C., and N. L. James. 1998. The effects of including white clover in perennial ryegrass swards and the height of mixed swards on the milk production, sward selection and ingestive behaviour of dairy cows. Anim. Sci. 67:195-202.

Ribeiro Filho, H., R. Delagarde, and J. Peyraud. 2003. Inclusion of white clover in strip-grazed perennial ryegrass swards: herbage intake and milk yield of dairy cows at different ages of sward regrowth. Anim. Sci. 77:499-510.

Ribeiro Filho, H., R. Delagarde, and J. Peyraud. 2005. Herbage intake and milk yield of dairy cows grazing perennial ryegrass swards or white clover/perennial ryegrass swards at low-and medium-herbage allowances. Anim. Feed Sci. Technol. 119:13-27.

Rodriguez, L. R. 2016. Interactions between pasture species and management and their implications for evaluating perennial ryegrass (Lolium perenne L.) cultivars in dairy systems. $\mathrm{PhD}$ Dissertation. Lincoln University, Lincoln, New Zealand.

Rutter, S., R. Orr, P. Penning, N. Yarrow, and R. Champion. 2002. Ingestive behaviour of heifers grazing monocultures of ryegrass or white clover. Appl. Anim. Behav. Sci. 76:1-9.

Rutter, S. M., R. J. Orr, N. H. Yarrow, and R. A. Champion. 2004 Dietary preference of dairy cows grazing ryegrass and white clover. J. Dairy Sci. 87:1317-1324.
Schils, R., T. Boxem, C. Jagtenberg, and M. Verboon. 2000a. The performance of a white clover based dairy system in comparison with a grass/fertiliser-N system. II. Animal production, economics and environment. NJAS Wagening. J. Life Sci. 48:305-318.

Schils, R., T. Boxem, K. Sikkema, and G. André. 2000b. The performance of a white clover based dairy system in comparison with a grass/fertiliser-N system. I. Botanical composition and sward utilisation. NJAS Wagening. J. Life Sci. 48:291-303.

Shalloo, L., A. Cromie, and N. McHugh. 2014. Effect of fertility on the economics of pasture-based dairy systems. Animal 8(Suppl. 1):222-231.

Smith, K. F., R. J. Simpson, R. A. Culvenor, M. O. Humphreys, M. P. Prud'Homme, and R. N. Oram. 2001. The effects of ploidy and a phenotype conferring a high water-soluble carbohydrate concentration on carbohydrate accumulation, nutritive value and morphology of perennial ryegrass (Lolium perenne L.). J. Agric. Sci. 136:65-74.

Søegaard, K. 1993. Nutritive value of white clover. Page 17-23 in White Clover in Europe: State of the Art. REUR Technical Series 29. J. Framen, comp. FAO, Rome, Italy.

Stilmant, D., P. Limbourg, and P. Lecomte. 2005. Assessment of cattle preference for perennial ryegrass varieties in association with white clover. Does white clover content interfere? J. Agron. Crop Sci. 191:233-240.

Tubritt, T., T. J. Gilliland, L. Delaby, N. McHugh, and M. O'Donovan. 2018. Comparison of grass utilisation performance of perennial ryegrass varieties. Pages 54-56 in Proc. of the 27th General Meeting of the European Grassland Federation, Cork, Ireland. Wageningen Academic Publishers, Wageningen, the Netherlands.

Van Soest, P. J. 1963. Use of detergents in the analysis of fibrous feeds. 2. A rapid method for the determination of fiber and lignin. J. Assoc. Off. Agric. Chem. 46:829-835.

van Vuuren, A. M., and P. Chilibroste. 2013. Challenges in the nutrition and management of herbivores in the temperate zone. Animal 7:19-28.

Wims, C. M., M. McEvoy, L. Delaby, T. M. Boland, and M. O'Donovan. 2013. Effect of perennial ryegrass (Lolium perenne L.) cultivars on the milk yield of grazing dairy cows. Animal 7:410-421.

Woodward, S. L., K. A. MacDonald, W. A. Carter, J. P. J. Eerens, and J. R. Crush. 2001. Milksolids production from different combinations of perennial ryegrass and white clover cultivars: II. Milksolids production and farm profitability. Proc. N.Z. Grassl. Assoc. 63:97-102. 